\title{
Effect of Malotilate (Diisopropyl 1,3-Dithiol-2-Ylidenemalonate) on Drug Metabolizing Activity in Rat Liver Microsomes
}

\author{
Hiroyasu OKUNO, Toshihiko MURASE, Sadao NAKANISHI, \\ Yasuko SHIOZAKI and Yoshiko SAMESHIMA \\ Third Department of Internal Medicine, Kansai Medical University, \\ Fumizono-cho, Moriguchi, Osaka 570, Japan \\ Accepted March 27, 1987
}

\begin{abstract}
The effect of malotilate (diisopropyl 1.3-dithiol-2-ylidenemalonate) on drug metabolizing activity in rat liver microsomes was examined. Malotilte (500 $\mathrm{mg} / \mathrm{kg} /$ day) was administered orally to rats for 3 days. The contents of cytochrome P-450 (P-450) and cytochrome $b_{5}\left(b_{5}\right)$, the activity of NADPH-cytochrome $c$ reductase, and the metabolization of aniline, aminopyrine, benzo(a)pyrene ( $B(a) P)$ and 7-ethoxycoumarin (7-EC) in the microsomal fraction were examined $24 \mathrm{hr}$ after the final administration of malotilate. The content of $b_{5}$ and the activity of $\mathrm{NADPH}$-cytochrome $c$ reductase were increased by the malotilate treatment, but the content of P-450 was not significantly affected. 7-EC O-deethylation was markedly and aminopyrine $\mathrm{N}$-demethylation was moderately enhanced; in contrast. aniline hydroxylation was significantly and $B(a) P$ hydroxylation was slightly reduced. Such different effects of malotilate among the four substrate-metabolizing activities may be due mainly to the increase in the content of $b_{5}$. which participates in the transport of the second electron required for $\mathrm{P}-450$ function to various extents. It is also possible that malotilate affects the population of P-450 subtypes, each having a different substrate specificity and a different affinity for $b_{5}$.
\end{abstract}

Diisopropyl 1,3-dithiol-2-ylidenemalonate (malotilate), which has been developed as a drug for liver cirrhosis, has protective effects in rats against liver injuries induced by carbontetrachloride $\left(\mathrm{CCl}_{4}\right)(1,2)$, ethionine (3). D-galactosamine (4) and many other hepatotoxins (5). It also attenuates the decreases in serum total protein and albumin contents, cholinesterase activity and total cholesterol level in human liver cirrhosis and chronic hepatitis (6).

Malotilate is known to enhance protein synthesis in the liver by accelerating RNA synthesis and/or increasing the transport of RNA from nuclei to cytosol (7). Indeed, it increased the regeneration rate of partial hepatectomized liver in cirrhotic rats (8) and in normal and aloxan-diabetic rats (9).

Malotilate has been reported to affect the hepatic microsomal mixed-function oxidase system. Nakayama (10) first described that malotilate increased the contents of cyto- chrome P-450 (P-450) and cytochrome $b_{5}$ $\left(b_{5}\right)$ and aminopyrine demethylase activity in rat liver microsomes and caused changes in the structures of rough and smooth endoplasmic reticulums in hepatocytes. Katoh et al. (11) demonstrated that malotilate characteristically increased the content of $b_{5}$ and the activity of NADPH-cytochrome $c$ reductase rather than the content of $P-450$ in rat liver microsomes. They also reported that $\mathrm{p}$-nitroanisole $\mathrm{O}$-demethylase activity and $\mathrm{N}$-demethylase activities toward aminopyrine, benzphetamine and ethylmorphine were enhanced, but aniline hydroxylase activity was reduced by malotilate administration (12). Recently, Kawata et al. (13) showed similar results. However, there are no reports concerning the effect of malotilate on any other substrate-metabolizing activity.

In the present study, we administered malotilate to rats for 3 days and examined the 
activity to metabolize the four substrates, aniline, aminopyrine benzo(a)pyrene $(B(a) P)$ and 7-ethoxycoumarin (7-EC), which are commonly used substrates for P-450 (1417), in the microsomal fraction of the liver

\section{Materials and Methods}

Animals and treatments: Male SpragueDawley rats each weighing $200 \mathrm{~g}$ were given a standard pelleted diet and drinking water ad libitum. Malotilate dissolved in olive oil $(10 \%$, $w / v)$ was administered orally to the rats at a dose of $500 \mathrm{mg} / \mathrm{kg}(1 \mathrm{ml} / 200 \mathrm{~g}$ body weight), once a day for 3 days. Control rats received equivalent volumes of olive oil. The animals were sacrificed $24 \mathrm{hr}$ after the final administration of the drugs. They were fasted for $18 \mathrm{hr}$ prior to killing, but had free access to tap water.

Preparation of microsomes: Rat liver micro somes were prepared as follows: Excised livers were thoroughly perfused with cold $0.15 \mathrm{M} \mathrm{KCl}$ and homogenized in 4-fold volumes of $0.15 \mathrm{M} \mathrm{KCl}$ solution containing $10 \mathrm{mM}$ EDTA using a Potter-type Tefion glass homogenizer. The homogenate was centrifuged at $10,000 \times \mathrm{g}$ for $15 \mathrm{~min}$ in a refrigerated centrifuge (Kubota, KR/20000). The supernatant was then centrifuged at $105,000 \times \mathrm{g}$ for $60 \mathrm{~min}$ in a preparative ultracentrifuge (Hitachi, 70P-72). The pellet of microsomes was suspended in the homogenating solution in the homogenizer and centrifuged again as described above. The resulting pellet was suspended in $20 \mathrm{mM}$ potassium phosphate buffer ( $\mathrm{pH}$ 7.4) containing $15 \%$ glycerol. These operations were done at $0-4^{\circ} \mathrm{C}$.

Assays of the contents of $P-450$ and $b_{5}$ and the activity of NADPH-cytochrome $c$ reductase: The content of $P-450$ was assayed by the method of Omura and Sato (18). The content of $b_{5}$ and the activity of NADPHcytocrome $c$ reductase were assayed by the method of Omura and Takesue (19). The microsomal protein content was measured by the method of Lowry et al. (20).

Assays of substrate-metabolizing activities: Substrate-metabolizing activities, aniline hydroxylation, aminopyrine $\mathrm{N}$-demethylation, $\mathrm{B}(\mathrm{a}) \mathrm{P}$ hydroxylation and 7-EC O-deethylation were assayed as described by Imai et al. (14). Nash (15), Nebert and Gelboin (16) and Ulirich and Weber (17). respectively. Each substrate-metabolizing activity was measured using NADPH as the sole electron source.

\section{Results}

Liver weight and the microsomal protein content in the liver of malotilate-treated rats: Figure 1 shows the liver weight $(/ 100 \mathrm{~g}$ body weight) and the microsomal protein content (/g liver) in the liver of the control and the malotilate-treated rats. The liver weight and the microsomal protein content in the liver of the malotilate-treated group were significantly increased to $156 \%$ and $113 \%$ of the control level, respectively.

Contents of P-450 and $b_{5}$ and the activity of NADPH-cytochrome $c$ reductase in malotilate-treated rats: As shown in Fig. 2. the content of $b_{5}$ and the activity of NADPHcytochrome $c$ reductase (/mg microsomal protein) of the malotilate-treated group were noticeably increased to $171 \%$ and $169 \%$ of the control level, respectively. On the other hand, the content of P-450 of the malotilatetreated group was decreased to $94.7 \%$ of the control level, no significant difference being observed between the malotilate-treated group and the control group.

Table 1 shows the contents of $\mathrm{P}-450$ and $b_{5}$ and the activity of NADPH-cytochrome $c$ reductase per $\mathrm{g}$ liver and per $\mathrm{mg}$ microsomal protein. They were similarly affected by the malotilate treatment, but the values per $g$ liver were higher than those per mg microsomal protein, which reflects the increase in the microsomal protein content per g liver.

Substrate-metabolizing activities in malotilate-treated rats: As shown in Fig. 3, 7-EC O-deethylase activity (/nmol P-450) in the malotilate-treated group was markedly enhanced to $614 \%$ of the control level. Likewise, aminopyrine $\mathrm{N}$-demethylase activity in the malotilate-treated group was moderately increased to $121 \%$ of the control level. In contrast, aniline hydroxylase activity was significantly reduced to $72.8 \%$ of the control level by the malotilate treatment: $B(a) P$ hydroxylase activity was also decreased to $85.1 \%$ of the control level, but no significant difference was observed between the malo- 
tilate-treated group and the control group.

Table 2 shows the activity to metabolize the four substrates per $\mathrm{mg}$ microsomal protein and per g liver, compared with that
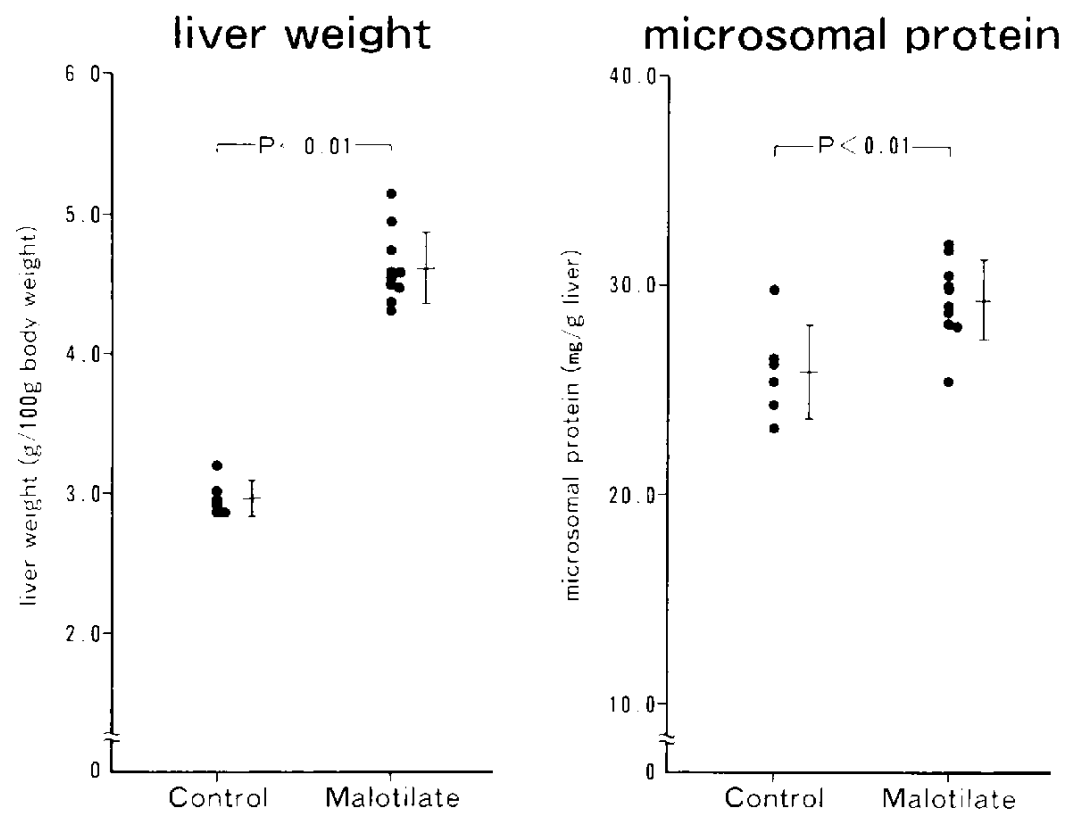

Fig. 1. The effect of malotilate on the liver weight and the microsomal protein content in the liver.
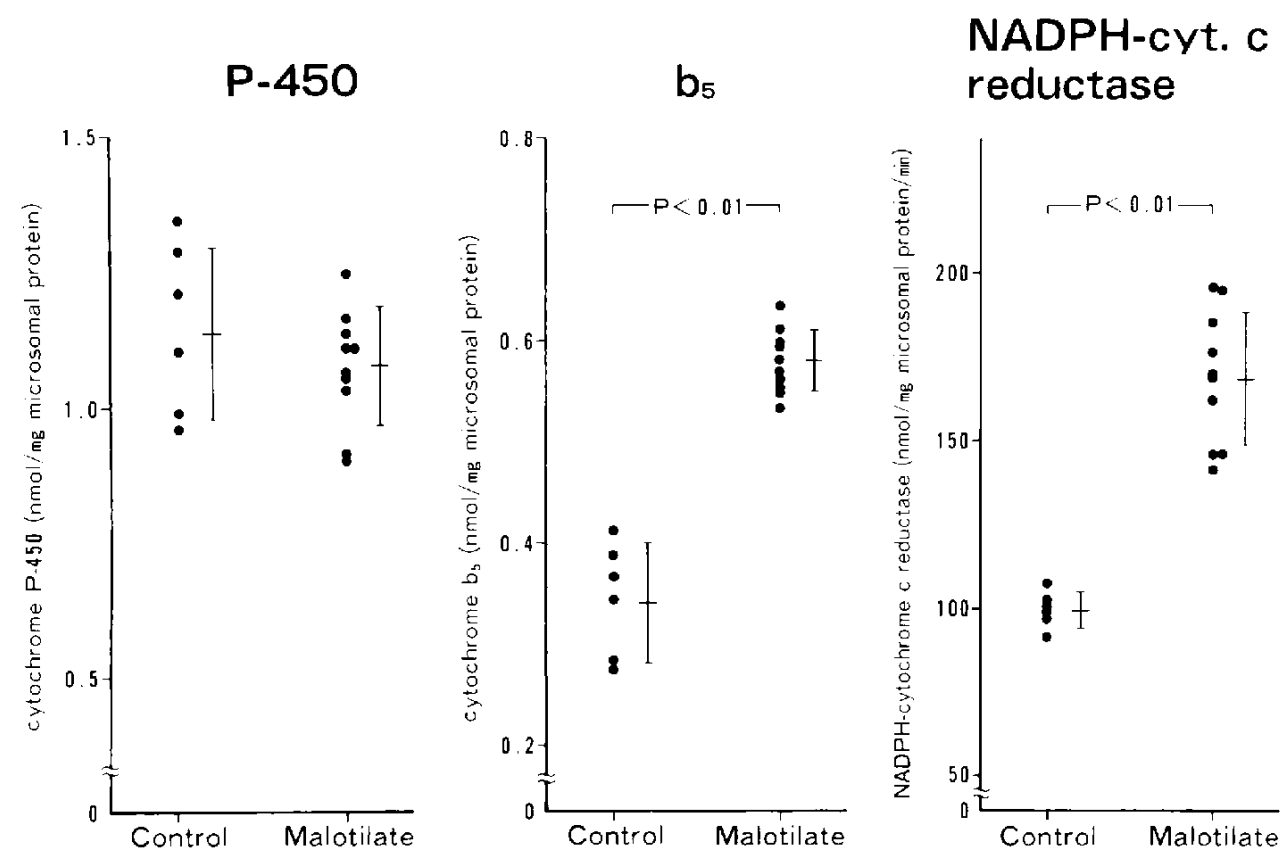

Fig. 2. The effect of malotilate on the contents of cytochromes P-450 and $b_{5}$ and the activity of NADPHcytochrome $c$ reductase per mg microsomal protein. 
H. Okuno et al.

Table 1. The effect of malotilate on the contents of cytochromes P-450 and $b_{5}$ and the activity of $\mathrm{NADPH}$-cytochrome $c$ reductase per $g$ liver and per mg microsomal protein

\begin{tabular}{|c|c|c|c|}
\hline & $\begin{array}{c}\mathrm{P}-450 \\
\text { (nmol/g liver) }\end{array}$ & $\begin{array}{c}b_{5} \\
\text { (nmol/g liver) }\end{array}$ & $\begin{array}{c}\text { NADPH-cyt. c reductase } \\
(\mu \mathrm{mol} / \mathrm{g} \mathrm{liver} / \mathrm{min})\end{array}$ \\
\hline Control $(C)(n=6)$ & $29.30 \pm 3.15$ & $8.83 \pm 1 . \overline{12}$ & $2.58 \pm 0.32$ \\
\hline Malotilate (M) $(n=10)$ & $31.43 \pm 2.78$ & $16.87 \pm 0.95^{*}$ & $4.95 \pm 0.74^{*}$ \\
\hline \multirow[t]{2}{*}{$M / C \times 100(\%)$} & 107 & 191 & 192 \\
\hline & $\begin{array}{c}\text { P-450 } \\
\text { (nmol/mg MS prot.) }\end{array}$ & $\begin{array}{c}b_{5} \\
\text { (nmol/mg MS prot.) }\end{array}$ & $\begin{array}{l}\text { NADPH-cyt. } C \text { reductase } \\
\text { (nmol/mg MS prot./min) }\end{array}$ \\
\hline Control (C) $(n=6)$ & $1.14 \pm 0.16$ & $0.34 \pm 0.06$ & $99.52 \pm 5.49$ \\
\hline Malotilate $(M)(n=10)$ & $1.08 \pm 0.11$ & $0.58 \pm 0.03^{*}$ & $168.55 \pm 19.73^{*}$ \\
\hline$M / C \times 100(\%)$ & 94.7 & 171 & 169 \\
\hline
\end{tabular}

(mean \pm S.D.). *Significantly different from the control $(P<0.01)$.

Table 2. The effect of malotilate on the four substrate-metabolizing activities per mg microsomal protein and per g liver, compared with those per nmol cytochrome P-450

\begin{tabular}{|c|c|c|c|c|}
\hline & $\begin{array}{c}\text { Aniline } \\
\text { (nmol/mg } \\
\mathrm{MS} \text { prot./min) }\end{array}$ & $\begin{array}{c}\text { Aminopyrine } \\
\text { (nmol/mg } \\
\text { MS prot./min) }\end{array}$ & $\begin{array}{c}\mathrm{B}(\mathrm{a}) \mathrm{P} \\
(\mathrm{nmol} / \mathrm{mg} \\
\mathrm{MS} \text { prot./min) }\end{array}$ & $\begin{array}{c}7-\mathrm{EC} \\
(\mathrm{nmol} / \mathrm{mg} \\
\mathrm{MS} \text { prot./min) }\end{array}$ \\
\hline Control (C) $(n=6)$ & $1.55 \pm 0.24$ & $15.71 \pm 4.58$ & $1.00 \pm 0.27$ & $0.26 \pm 0.05$ \\
\hline Malotilate $(M)(n=10)$ & $1.06 \pm 0.15^{* *}$ & $17.50 \pm 2.21$ & $0.79 \pm 0.14$ & $1.43 \pm 0.30^{* *}$ \\
\hline \multirow[t]{2}{*}{$\mathrm{M} / \mathrm{C} \times 100(\%)$} & 68.4 & 111 & 79.0 & 550 \\
\hline & $\begin{array}{r}\text { Aniline } \\
\text { (nmol/g } \\
\text { liver/min) } \\
\end{array}$ & $\begin{array}{c}\text { Aminopyrine } \\
\text { (nmol/g } \\
\text { liver/min) }\end{array}$ & $\begin{array}{c}\mathrm{B}(\mathrm{a}) \mathrm{P} \\
(\mathrm{nmol} / \mathrm{g} \\
\text { liver/min) }\end{array}$ & $\begin{array}{c}7-\mathrm{EC} \\
\text { (nmol/g } \\
\text { liver/min) }\end{array}$ \\
\hline Control $(C)(n=6)$ & $39.66 \pm 5.36$ & $401.08 \pm 101.73$ & $25.66 \pm 6.36$ & $6.62 \pm 1.12$ \\
\hline Malotilate $(M)(n=10)$ & $31.06 \pm 3.84^{* *}$ & $511.02 \pm 59.41^{*}$ & $23.11 \pm 4.18$ & $42.00 \pm 10.01^{* *}$ \\
\hline \multirow[t]{2}{*}{$\mathrm{M} / \mathrm{C} \times 100(\%)$} & 77.7 & 127 & 90.1 & 634 \\
\hline & $\begin{array}{c}\text { Aniline } \\
(n \mathrm{nmol} / \mathrm{nmol} \\
\mathrm{P}-450 / \mathrm{min})\end{array}$ & $\begin{array}{l}\text { Aminopyrine } \\
(\mathrm{nmol} / \mathrm{nmol} \\
\mathrm{P}-450 / \mathrm{min})\end{array}$ & $\begin{array}{c}\mathrm{B}(\mathrm{a}) \mathrm{P} \\
(\mathrm{nmol} / \mathrm{nmol} \\
\left.\mathrm{P}_{-} 450 / \mathrm{min}\right)\end{array}$ & $\begin{array}{c}\text { 7-EC } \\
(\mathrm{nmol} / \mathrm{nmol} \\
\mathrm{P}-450 / \mathrm{min})\end{array}$ \\
\hline Control $(C)(n=6)$ & $1.36 \pm 0.10$ & $13.57 \pm 2.41$ & $0.87 \pm 0.15$ & $0.22 \pm 0.02$ \\
\hline Malotilate $(M)(n=10)$ & $0.99 \pm 0.13^{* *}$ & $16.36 \pm 2.31^{*}$ & $0.74 \pm 0.17$ & $1.35 \pm 0.36^{* *}$ \\
\hline$M / C \times 100(\%)$ & 72.8 & 121 & 85.1 & 614 \\
\hline
\end{tabular}

(mean \pm S.D.). ${ }^{*}$ Significantly different from the control $\left({ }^{*} P<0.05,{ }^{* *} P<0.01\right)$.

per nmol P-450. They were similarly affected by the malotilate treatment, but the activity per mg microsomal protein was lower than that per $\mathrm{nmol} P-450$. which reflects the slight decrease in the content of P-450 per mg microsomal protein; the activity per $g$ liver was higher than that per nmol P-450, which reflects the slight increase in the content of P-450 per g liver.

\section{Discussion}

This study confirmed that the content of $b_{5}$ and the activity of NADPH-cytochrome $c$ reductase were noticeably increased, whereas the content of P-450 was not significantly affected by the malotilate treatment; aminopyrine $\mathrm{N}$-demethylase activity was moderately increased, but aniline hydroxylase activity was significantly reduced, as described by others 

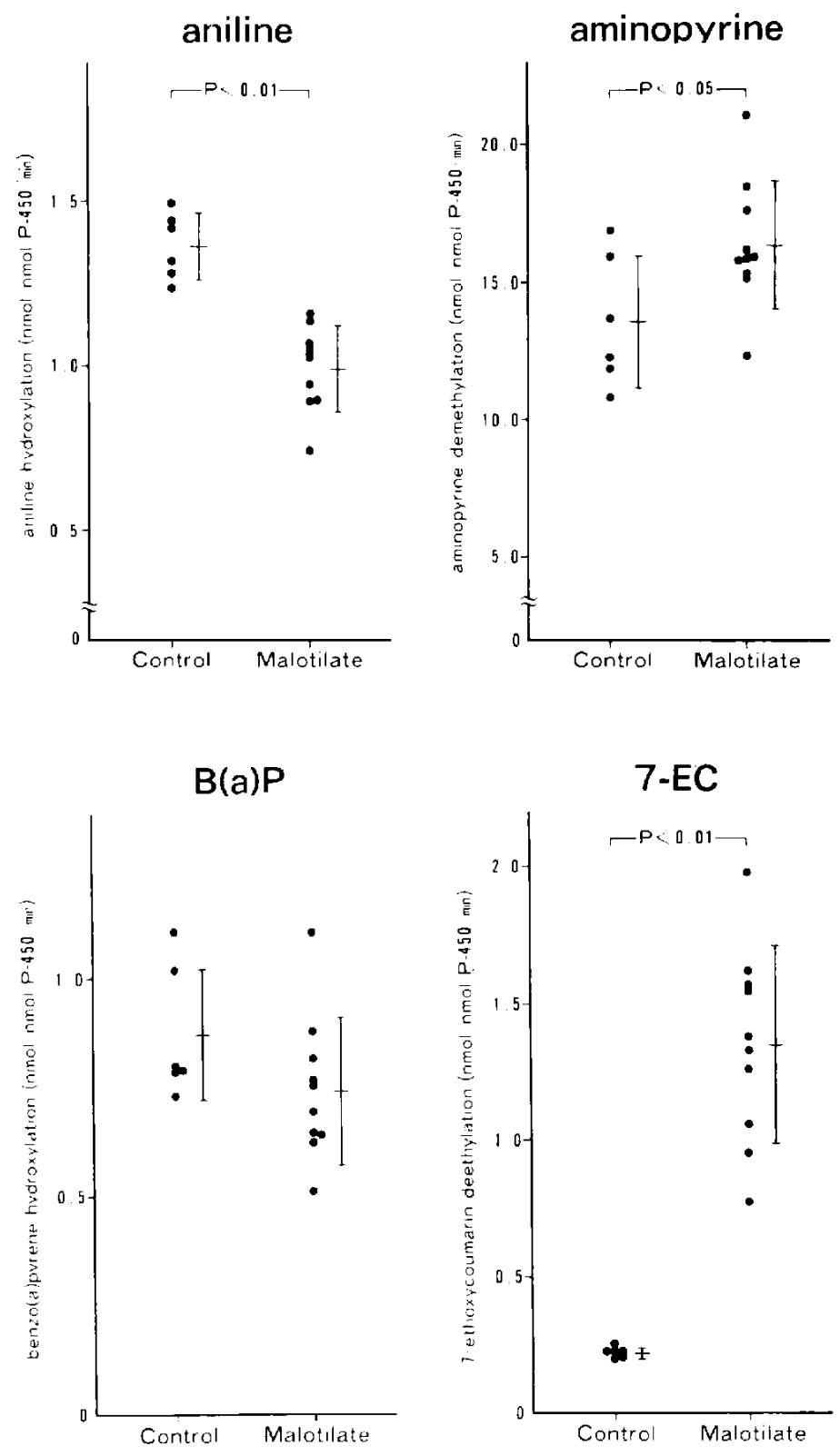

Fig. 3. The effect of malotilate on the activities of aniline hydroxylase, aminopyrine $\mathrm{N}$-demethylase. benzo(a)pyrene (B(a)P) hydroxylase and 7-ethoxycoumarin (7-EC) O-deethylase per nmol cytochrome P- 450 .

(10-13). In addition. 7-EC O-deethylase activity was preferentially and markedly enhanced to more than 6 times the control level, whereas $B(a) P$ hydroxylase activity was slightly decreased by the malotilate treatment. Liver microsomes contain two electron transport chains, NADPH-supported and NADH-supported systems. Hildebrandt and Estabrook (21) first suggested the participation of $b_{5}$, the component of the $\mathrm{NADH}$ supported system, in the microsomal mixedfunction oxidase system, indicating that it 
provides the second of the two electrons required for $\mathrm{P}-450$ function. Since then, various studies (22-31) have been reported. and it is generally accepted that some crosslinking sites exist between the two chains and both of them contribute to the mixed function oxidase system in liver microsomes.

When NADPH is used as the sole electron source as in our experiments, the second electron is provided from NADPH-cytochrome $c$ reductase either directly or via $b_{5}$ to P-450. However, the participation of $b_{5}$ in the transport of the second electron differs among the substrates examined $(22-26)$ as well as the subtypes of P-450 included in the system $(25-28)$ and depends on the conditions employed, such as the concentration of $b_{5}$, if the same substrate and P-450 are used $(29-31)$.

$\mathrm{NADPH}$-cytochrome $c$ reductase is the rate-limiting component in the mixedfunction oxidase system. The fortification of microsomes with purified NADPH-cytochrome $c$ reductase enhances the drug metabolizing activity. which depends on both the subtype(s) of P-450 and the substrate examined (32, 33). Indeed, some drug metabolizing activities are reduced with the increase in the amount of $b_{5}$ in reconstituted systems, but partially reversed by the increase in the concentration of NADPH-cytochrome $c$ reductase $(31)$.

The effect of malotilate on various substrate-metabolizing activities may result from the increases in both the content of $b_{5}$ and the activity of NADPH-cytochrome $c$ reductase. Studies using the antibody for $b_{5}$ (23) and reconstituted systems (13, 24) have shown that $b_{5}$ is not involved in aniline hydroxylation. Therefore, in the case of aniline hydroxylation, $P-450$ and $b_{5}$ may compete for the second electron from NADPH-cytochrome $c$ reductase, and the increase in the content of $b_{5}$ by the malotilate treatment, thus, may inhibit aniline hydroxylase activity, though the increase in the activity of NADPH-cytochrome $c$ reductase may have partially reversed this inhibition.

7-EC O-deethylation is markedly enhanced by the addition of $b_{5}$ in the reconstituted system containing some form of P-450 ( $P$ $450_{1}$, etc.) (28). The fortification of micro- somes with purified NADPH-cytochrome $c$ reductase also increases 7 - $E C O$-deethylation $(32,33)$. Therefore, the increases in both the content of $b_{5}$ and the activity of NADPHcytochrome $c$ reductase by the malotilate treatment may have synergistically enhanced 7-EC O-deethylase activity.

Imai (22) reported that aminopyrine $\mathrm{N}$ demethylation was enhanced by the addition of $b_{5}$ in the reconstituted system containing P-4501. Recently, Kawata et al. (13) showed similar results. However, Jansson and Schenkman (29) demonstrated that aminopyrine $\mathrm{N}$-demethylation was gradually inhibited when increasing concentrations of $b_{5}$ were added to liver microsomes of untreated or phenobarbital-treated rats.

Noshiro et al. (23) reported that the antibody for $b_{5}$ strongly inhibited $B(a) P$ hydroxylation in mouse liver microsomes and suggested that $b_{5}$ was the essential component for $B(a) P$ hydroxylation. However, Lu et al. (31) demonstrated that B(a)P hydroxylation in the reconstituted system containing P-448 was gradually reduced in proportion to the increase in the amount of $b_{5}$. but partially reversed by the increase in the concentration of NADPH-cytochrome $c$ reductase. The incorporation of purified NADPH-cytochrome $c$ reductase into microsomal preparations also enhanced $\mathrm{B}(\mathrm{a}) \mathrm{P}$ hydroxylation (32).

In the cases of aminopyrine $\mathrm{N}$-demethylation and $B(a) P$ hydroxylation, the extent of the participation of $b_{5}$ in the transport of the second electron may be between that of aniline hydroxylation and 7-EC O-deethylation. Under the conditions of our experiments, the increase in the content of $b_{5}$ by the malotilate treatment may have slightly increased or decreased aminopyrine $N$ demethylase activity and decreased $B(a) P$ hydroxylase activity, although they may have been reversed by the increase in the activity of NADPH-cytochrome $c$ reductase.

Kawata et al. (13) recently demonstrated using reconstituted systems that the stimulatory effect of $b_{5}$ on p-nitroanisole $\mathrm{O}$ demethylase activity and $\mathrm{N}$-demethylase activities toward aminopyrine and benzphetamine in the $\mathrm{P}-450$ preparation from malotilate-treated rats was more conspicuous than 
that in the preparation from control rats. They suggested that the microsomes of the malotilate-treated rats contained a form (s) of P-450 which required $b_{5}$ for the maximal activities of the demethylation reactions. In our studies, too, it is possible that malotilate induced a form(s) of P-450 which had a substrate specificity preferential to 7-EC or that which had a high affinity for $b_{5}$ and accepted the second electron preferentially from $b_{5}$ in 7 -EC O-deethylation.

\section{References}

1 Nakayama, S., Gotoh, H., Oguchi, E., Okazaki, M. and Sakamoto, K.: Effect of disopropyl 1,3dithiol-2-ylidenemalonate (malotilate) on $\mathrm{CCl}_{4}$ induced liver damage in rats. J. Med. Soc. Showa 42, 605-611 (1982) (Abs. in English)

2 Katoh, M. and Sugimoto, T.: Effect of malotilate on chronic liver injury induced by carbon tetrachloride in rats. Folia Pharmacol. Japon. 80 , 83-91 (1982) (Abs. in English)

3 Nakayama, S., Sakai, S., Kurimoto, T., Kato, H. and Okazaki, M.: Pharmacological studies of diisopropyl 1.3-dithiol-2-yidenemalonate (NKK105): Report 5; Effects of NKK-105 on ethionineinduced fatty liver in rats. J. Med. Soc. Showa 39. 613-620 (1979) (Abs. in English)

4 Hirooka, S.; Tanaka, T.; Nokata, M., Katoh, M. and Sugimoto, T.: Effect of malotilate on hepatic injury induced by D-galactosamine in rat. lyakuhin Kenkyu 13, 1046-1052 (1982) (Abs. in English)

5 Katoh, M., Nokata, M., Sugimoto, T. and Kasai, T.: Protective effect of diisopropyl 1,3-dithiol-2ylidenemalonate (NKK-105) on chemically induced liver injury. Japan. J. Pharmacol. 28, Supp. 125P (1978)

6 Suzuki, H., Ichida, F., Takino, T., Nagashima, H., Hirayama, C., Fujisawa, K., Furuta, S., Monna, T., Yamamoto, S. and Oda, T.: Therapeutic effects of malotilate on chronic hepatitis and liver cirrhosis: A double blind, controlled multicenter trial. In Hepatotrophic Agent Malotilate. Proceedings of a Symposium on Malotilate held at the 7th World Congress of Gastroenterology. Stockholm. June 15, 1982. Edited by Oda. T. and Tygstrup, N., p. 54-68, Excerpta Medica, Amsterdam. Princeton. Geneva and Tokyo (1983)

7 Imaizumi, Y., Katoh, M., Sugimoto, T. and Kasai, T.: Effect of malotilate (diisopropyl 1.3-dithiol-2ylidenemalonate) on the protein synthesis in rat liver. Japan. J. Pharmacol. 32, 369-375 (1982)

8 Igarashi, S., Hatahara, T. and Oda, T.: Effects of diisopropyl 1,3-dithiol-2-ylidenemalonate (NKK105) on cell proliferation and protein metabolism in the liver of rat and mouse. Acta Hepatol. Japon. 21, 1-7 (1980) (Abs. in English)

9 Niwano, Y., Katoh, M., Uchida, M. and Sugimoto, T.: Acceleration of liver regeneration by malotilate in partially hepatectomized rats. Japan. J. Pharmacol. 40, 411-415 (1986)

10 Nakayama, S.: Effects of diisopropyl 1,3-dithiol2-ylidenemalonate (NKK-105) on the drugmetabolizing enzymes and fine structure of rat liver. Folia Pharmacol. Japon. 75, 571-584 (1979) (Abs, in English)

11 Katoh, M., Kitada, M., Satoh, T., Kitagawa, H., Sugimoto, T. and Kasai, T.: Effect of diisopropyl 1,3-dithiol-2-ylidenemalonate on microsomal electron transport system in rat liver. J. Pharmacobiodyn. 3, 261-263 (1980)

12 Katoh, M., Kitada, M., Satoh, T., Kitagawa, H., Sugimoto, T, and Kasai, T.: Further studies on the in vivo effect of disopropyl 1,3-dithiol-2ylidenemalonate (NKK-105) on the liver microsomal drug oxjdation system in rats. Biochem. Pharmacol. 30, 2759-2765 (1981)

13 Kawata, S., Sugiyama, T., Seki, K., Tarui, S., Okamoto, $M$. and Yamano, T.: Stimulatory effect of cytochrome $b_{5}$ induced by $p$-nitroanisole and diisopropyl 1,3-dithiol-2-ylidenemalonate on rat liver microsomal drug hydroxylations. J. Biochem. 92, 305-313 (1982)

14 Imai, Y., Ito, A. and Sato, R.: Evidence for biochemically different types of vesicles in the hepatic microsomal fraction. J. Biochem. 60, 417-428 (1966)

15 Nash, T.: The colorimetric estimation of formaldehyde by means of the Hantzsch reaction. Biochem. J. 55, 416-421 (1953)

16 Nebert, D.W. and Gelboin, H.V.: Substrateinducible microsomal aryl hydroxylase in mammalian cell culture. J. Biol. Chem. 243, 62426249 (1968)

17 Ullrich, $V$. and Weber, P.: The O-dealkylation of 7-ethoxycoumarin by liver microsomes. Hoppe Seylers Z. Physiol. Chem. 353, 1171-1177 (1972)

18 Omura, T. and Sato, R.: The carbon monoxidebinding pigment of liver microsomes. J. Biol. Chem. 239, 2370-2385 (1964)

19 Omura, T. and Takesue, S.: A new method for simultaneous purification of cytochrome $b_{5}$ and NADPH-cytochrome $c$ reductase from rat liver microsomes. J. Biochem. 67, 249-257 (1970)

20 Lowry, O.H., Rosebrough, N.J., Farr, A.L. and Randall, R.J.: Protein measurement with the Folin phenol reagent. J. Biol. Chem. 193, 265- 
275 (1951)

21 Hildebrandt, A. and Estabrook, R.W.: Evidence for the participation of cytochrome $b_{5}$ in hepatic microsomal mixed-function oxidation reactions. Arch. Biochem. Biophys. 143, 66-79 (1971)

22 Imai, Y.: The roles of cytochrome $b_{5}$ in reconstituted monooxygenase systems containing various forms of hepatic microsomal cytochrome P450. J. Biochem. 89, 351-362 (1981)

23 Noshiro, M., Harada, N. and Omura, T.: Immunochemical study on the participation of cytochrome $b_{5}$ in drug oxidation reactions of mouse liver microsomes. Biochem. Biophys. Res. Commun. 91, 207-213 (1979)

24 Kitada, M., Yamaguchi, N., Rikihisa, T., Kanakubo, $Y$. and Kitagawa, $\mathrm{H}$.: Effects of cytochrome $b_{5}$ on aniline hydroxylation catalyzed by a reconstituted system containing acetone or $2,2^{\prime}$ bipyridine. Japan. J. Pharmacol, 40, 347-349 (1986)

25 Sugiyama, T., Miki, N. and Yamano, T.: The obligatory requirement of cytochrome $b_{5}$ in the $\mathrm{p}$-nitroanisole $\mathrm{O}$-demethylation reaction catalyzed by cytochrome P- 450 with a high affinity for cytochrome $b_{5}$. Biochem. Biophys. Res. Commun. 90, 715-720 (1979)

26 Kuwahara, S, and Omura, T.: Different requirement for cytochrome $b_{5}$ in NADPH-supported $\mathrm{O}$-deethylation of $\mathrm{p}$-nitrophenetole catalyzed by two types of microsomal cytochrome P-450. Biochem. Biophys. Res. Commun. 96, 1562$1568(1980)$

27 Lu, A.Y.H. and Levin, W.: Liver microsomal electron transport systems: III. The involvement of cytochrome $b_{5}$ in the NADPH-supported cytochrome P-450-dependent hydroxylation of chlorobenzene. Biochem. Biophys. Res. Commun. 61, 1348-1355 (1974)

28 Imai, Y.: Reconstituted O-dealkylase systems containing various forms of liver microsomal cytochrome P-450. J. Biochem. 86, 1697-1707 (1979)

29 Jansson, I. and Schenkman, J.B.: Evidence against participation of cytochrome $b_{5}$ in the hepatic microsomal mixed-function oxidase reaction. Mol. Pharmacol. 9, 840-845 (1973)

30 Hrycay, E.G. and Estabrook, R.W.: The effect of extra bound cytochrome $b_{5}$ on cytochrome $P$ 450-dependent enzyme activities in liver microsomes. Biochem. Biophys. Res. Commun. 60, 771-778 (1974)

31 Lu, A.Y.H., West, S.B., Vore, M., Ryan, D. and Levin, $W$ : Role of cytochrome $b_{5}$ in hydroxylation by a reconstituted cytochrome P-450containing system. J. Biol. Chem. 249, 67016709 (1974)

32 Miwa, G.T., West, S.B. and Lu, A.Y.H.: Studies on the rate-limiting enzyme component in the microsomal monooxygenase system: Incorporation of purified NADPH-cytochrome $c$ reductase and cytochrome $\mathrm{P}-450$ into rat liver microsomes. J. Biol. Chem. 253, 1921-1929 (1978)

33 Kamataki, T., Ando, M., Yamazoe, Y., Ishii, K. and Kato, R.: Sex difference in the O-dealkylation activity of 7-hydroxycoumarin 0 -alkyl derivatives in liver microsomes of rats. Biochem. Pharmacol. 29, 1015-1022 (1980) 